\title{
Effectiveness of Tocilizumab after Switching from Intravenous to Subcutaneous Formulation in Patients with Rheumatoid Arthritis: A Single-Centre Experience
}

\author{
Sonja Stojanović1,2, Bojana Stamenković1,2, Jovan Nedović1, Ivana Aleksići, \\ Jovana Cvetković ${ }^{1}$ \\ 1Institut for Treatment and Rehabilitation "Niška Banja", Niška Banja, Serbia \\ ${ }^{2}$ University of Niš, Faculty of Medicine, Niš, Serbia
}

SUMMARY

Nowadays, the appropriate control of rheumatoid arthritis (RA) involves the absence of clinical disease activity, delaying joint destruction as long as possible and adequate quality of life of the affected. With currently available therapeutic modalities, this therapeutic goal can be achieved in a large number of patients.

The aim of this research was to determine the effectiveness of an IL-6 blocker (Tocilizumab) in patients with RA in everyday clinical practice. We also analyzed whether a change in the mode of drug administration (switching from intravenous to subcutaneous drug formulation) had an impact on drug effectiveness (using the DAS 28 SE and CDAI indexes) and quality of life of patients with RA (HAQ, Beck Depression Inventory, FACIT F score and SF 36 questionnaire). The study included 53 subjects diagnosed with RA, treated with Tocilizumab.

After a six-month use of subcutaneous Tocilizumab, we concluded that the method of drug administration did not have an impact on its effectiveness and on all the examined parameters of quality of life assessment.

Key words: Charlson Comorbidity Index, criterion validity, reliability, community-dwelling older adults, Iran 


\section{INTRODUCTION}

Rheumatoid arthritis (RA) is a chronic, inflammatory, autoimmune disease of unknown etiology, characterized by pain, swelling and destruction of synovial joints. If the disease has an aggressive course and if it is inadequately treated, it may lead to significant invalidity and premature mortality. Although it is predominantly limited to joints, a part of the clinical picture of RA may involve various non-joint manifestations. Different systems and organs may be involved with inflammation and immunological disorders, which gives this disease its systemic character.

RA is the most common inflammatory arthropathy, affecting about $1 \%$ of the global population. The prevalence of the disease in our country is about $0.35 \%$ (1).

The gold standard in the treatment of rheumatoid arthritis is still Methotrexate (MTX). However, a significant advance in RA therapy has been made since the introduction of biological diseasemodifying antirheumatic drugs, (bDMARDs), primarily TNF- $\alpha$ inhibitors, then B cell depressants and IL-6 receptor blockers, and most recently Janus kinase inhibitors (JAKs). According to the official recommendations for RA treatment (2), the use of biological drugs and JAKs represents an optimal approach, together with conventional synthetic disease-modifying antirheumatic drug (cs DMARD), except for the cases with contraindications or those who cannot tolerate csDMARD, IL-6 blockers registered for RA treatment as monotherapy should be given preference.

Tocilizumab (TCZ) is the first recombinant humanized monoclonal antibody against IL-6 receptor (both membrane-bound and soluble) approved for RA treatment. In Europe, it has been available since 2009, at first as an intravenous formulation (iv-TCZ), 4 or $8 \mathrm{mg} / \mathrm{kg}$ body weight, every 28 days. Since 2015, it has also been administered as a subcutaneous drug formulation (sc-TCZ), 162 mg every 7 days.

In patients with moderately to highly active RA, subcutaneous Tocilizumab formulation has not been shown to be inferior to intravenous formulation, either in terms of its effectiveness or its safety (3). Moreover, it has been reported that Tocilizumab maintains its therapeutic effectiveness after switching from intravenous to subcutaneous administration (4). For the time being, there is no infor- mation from clinical practice in our country about the maintenance of therapeutic effectiveness of IL- 6 blockers after switching from one administration method to another, especially when taking into consideration the assessment of RA patients themselves.

\section{PATIENTS AND METHODS}

\section{Patients}

The study was performed at the Rheumatology Clinic of the Institute for treatment and Rehabilitation "Niška Banja“. It was designed as an observational cross-sectional study, involving 53 subjects with confirmed RA diagnosis (all of them fulfilled the ACR/EULAR 2010 classification criteria for RA). The average time to RA diagnosis was $64.3 \pm 30.3$ months. The patients were above 18 years old and most of them $(75.5 \%)$ were women. At the cross-sectional observation point, all the patients were treated with Tocilizumab together with standard diseasemodifying therapy. Tocilizumab was administered as monotherapy in $15.09 \%$ of patients, while in most of them $(84.91 \%)$ it was given combined with cs DMRD, predominantly Methotrexate $(85.71 \%$ of patients). The average MTX dose was $13.25 \mathrm{mg}$ a week. Tocilizumab was most commonly the first biological drug in the studied group - in 24 patients $(45.28 \%)$. In 19 patients (35.85\%) it was administered after the first bDMARD; in 7 (13.20\%) patients after two prior bDMARDs; in $4(3.17 \%)$ after three bDMARDs; and in $1(1.9 \%)$ patient after four bDMARDs.

The average duration of TCZ-iv treatment before switching to sc-TCZ was $44 \pm 14$ months.

At the observation point, out of 53 patients, 6 $(11.32 \%)$ patients continued with iv-TCZ, while 47 $(88.68 \%)$ were receiving subcutaneous TCZ therapy. Out of these, 20 were treated with sc-TCZ from the beginning of their treatment with the drug, while 27 had switched from intravenous to subcutaneous therapy. All the patients receiving sc-TCZ had been treated with this formulation for more than 6 months.

Prior to inclusion in the study, all the subjects were informed about the study goals and signed their informed consent forms. The study was approved by the Ethics Committee of the Institute for treatment and Rehabilitation "Niška Banja“. 


\section{Methods}

In all the patients, the number of tender and swollen joints was established for the purpose of determination of composite indexes DAS 28 SE (Disease Activity Score) and CDAI (Clinical Disease Activity Index), which in addition to clinical parameters involved the assessment of disease severity by both the patients and doctors on a visual analogue scale $(0-100 \mathrm{~mm})$ and erythrocyte sedimentation rate. The level of disease activity was interpreted as high if DAS 28 SE was > 5.1; moderate, if DAS 28 SE was 3.2-5.1; and low if DAS $28 \mathrm{SE}$ was $\leq 3.2$. If DAS 28 SE was below 2.6, the disease was considered to be in remission (5). According to CDAI, the disease was in remission if the index was below 2.8; $2.9-10$ corresponded to low disease activity; $10.01-22$, to moderate disease activity; and 22.1 - 76 to high disease activity (6). The HAQ questionnaire (patientcompleted) assessed the functional ability of RA patients, analyzing everyday activities of RA patients (7). The patient-completed outcome assessment indexes (PRO - Patient Reported Outcomes) used in the study were the Beck Depression Inventory (8), FACIT F (Functional Assessment Chronic Illness Therapy) score for self-reported fatigue (9), and SF 36 (Short-Form 36) questionnaire for quality of life assessment (10). The results of the analysis of this questionnaire were translated into three summary scales: „physical scale“ (SF-F); „mental scale“ (SF-M) and "general health scale" (SF-GH).

Statistical analysis for the numeric variables are presented as arithmetic mean \pm standard deviation. Comparison of continuous variables was performed by the Mann-Whitney test. The hypothesis was tested with a significance threshold $p<0.05$.

\section{RESULTS}

Out of 53 RA patients treated with iv-TCZ, 47 $(88.68 \%)$ switched to sc-TCZ, while $6(11.32 \%)$ continued with iv-TCZ.

Using the composite indexes DAS 28 SE and CDAI, we analyzed the therapeutic effectiveness of Tocilizumab in all 53 patients. At the observation point, in $25(47.17 \%)$ patients the disease was in remission according to DAS $28 \mathrm{SE}$. With DAS $28 \mathrm{SE}$, low disease activity was found in 24 (45.28\%), while $4(7.55 \%)$ had moderate disease activity. The therapeutic goal (according to DAS $28 \mathrm{SE}$ ) was achieved in $92.45 \%$ of patients (Graph 1A). According to CDAI, in more than half of patients $(60.38 \%)$ low disease activity was found, remission in 11 (20.75\%), moderate disease activity in $9(16.98 \%)$, while 1 $(1.89 \%)$ patient had high disease activity. According to CDAI, the therapeutic goal was achieved in 43 $(81.13 \%)$ patients with RA (Graph 1B). The functional status, as measured with HAQ index, was 0.89

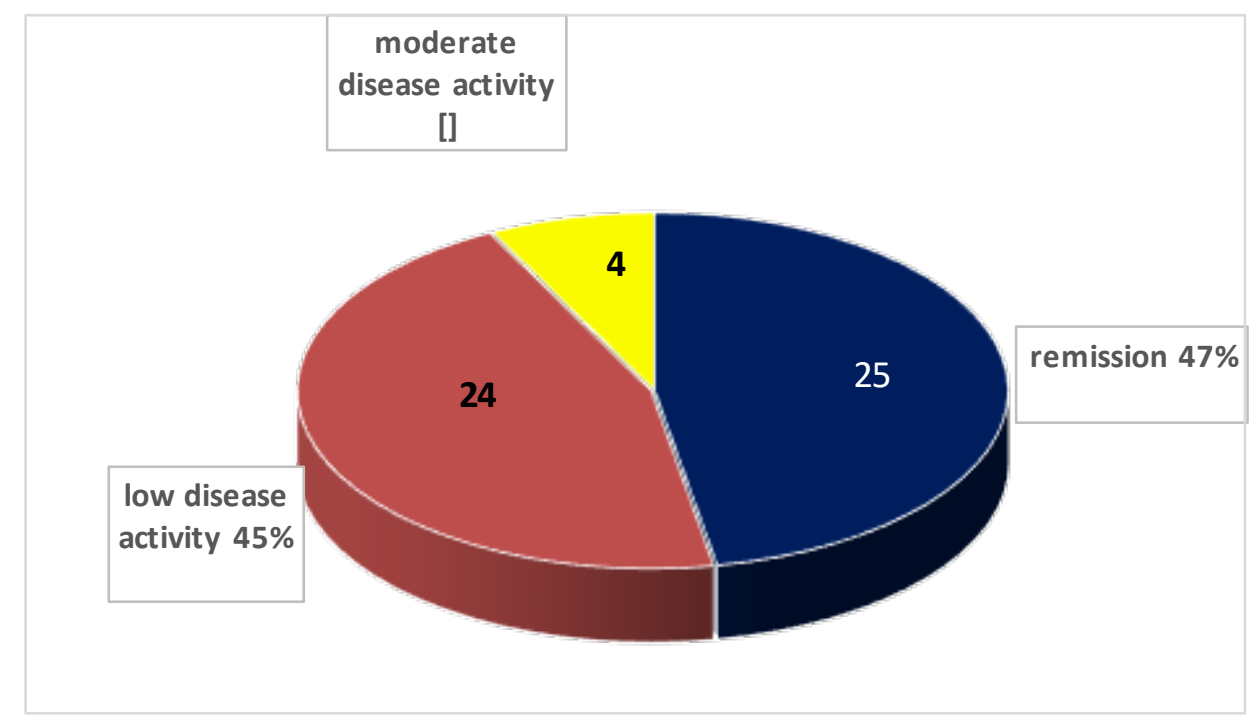

Graph 1A. RA activity measured with DAS 28 SE at the point of observation (whole group) 


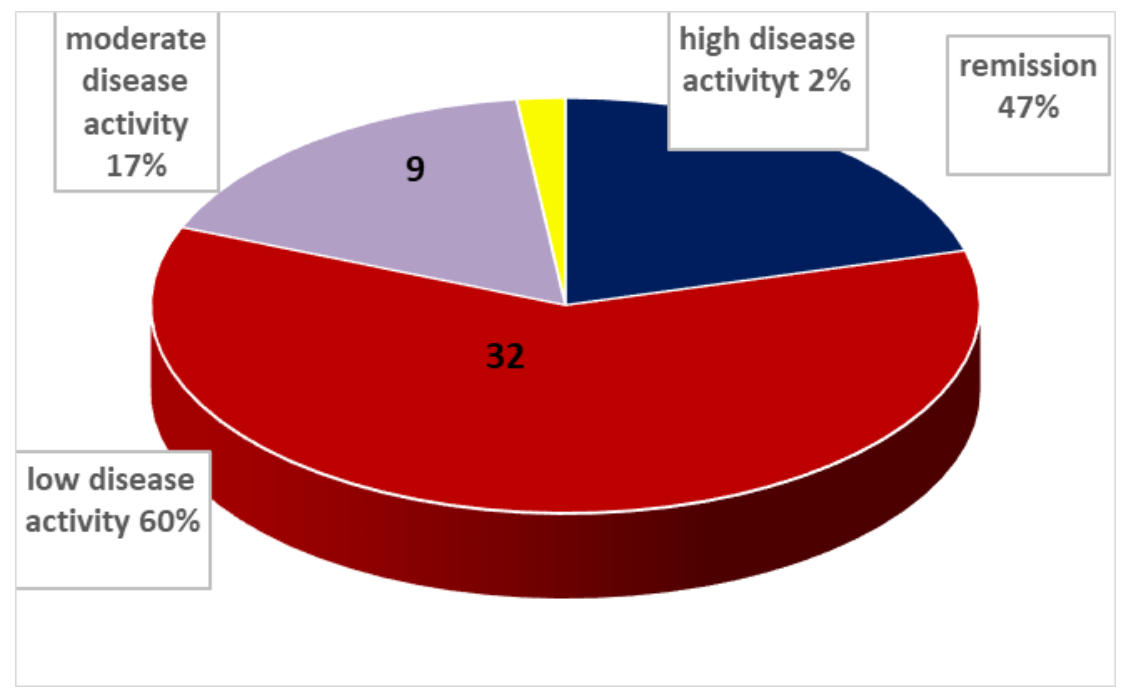

Graph 1B. RA activity measured with CDAI at the point of observation (whole group)

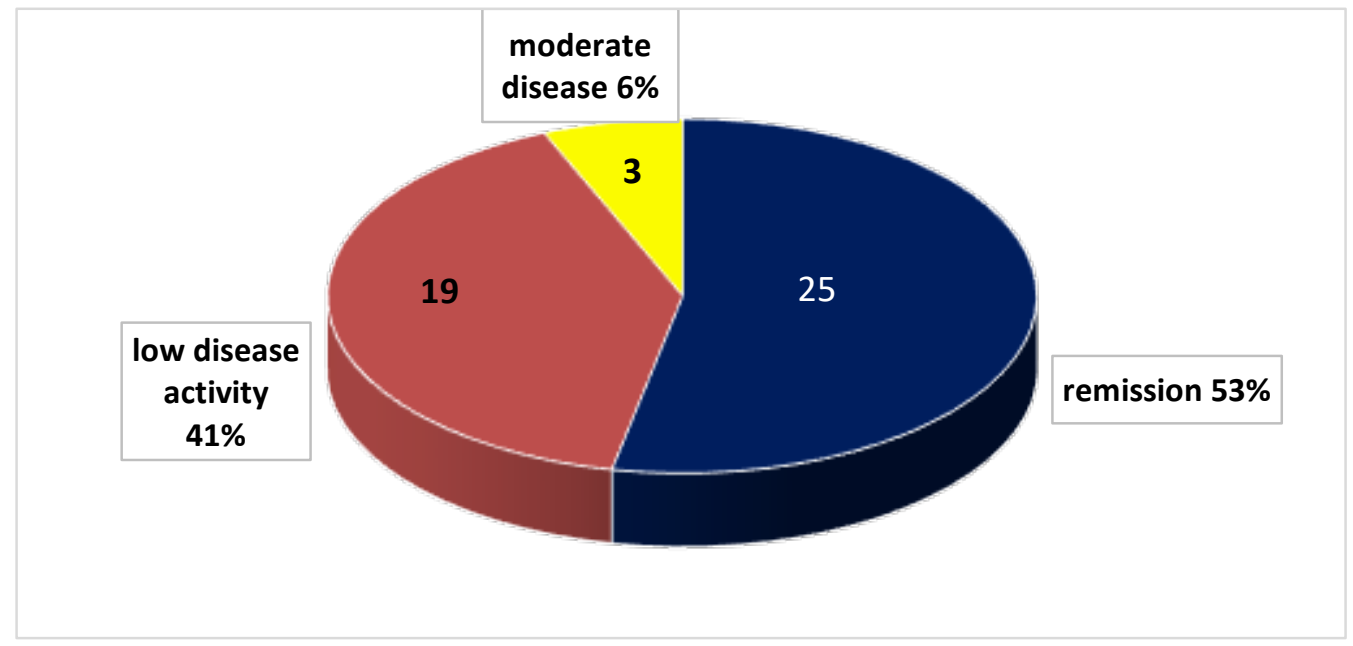

Graph 2A. RA activity measured with DAS 28 SE in patients on SC TCZ at the observation point

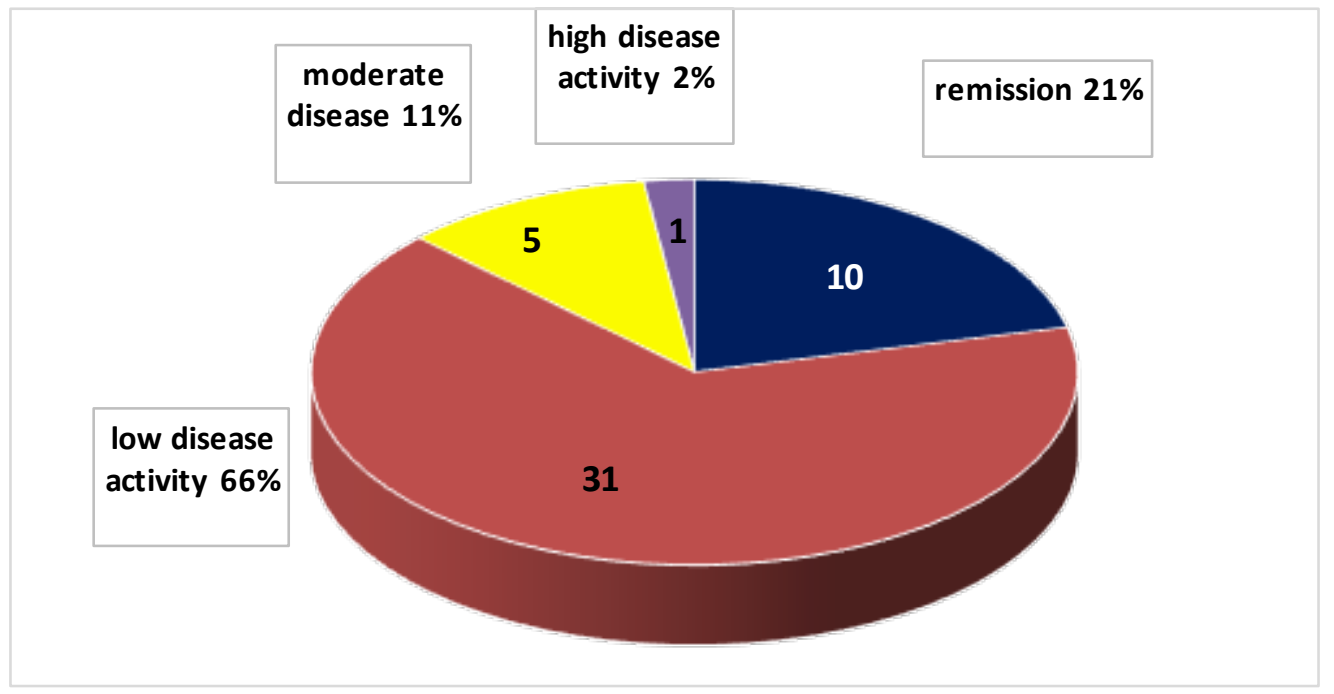

Graph 2B. RA activity measured with CDAI in patients on SC TCZ at the observation point 
at the observation point for the whole group, corresponding to a low degree of functional damage.

The analysis of disease activity (according to DAS $28 \mathrm{SE}$ ) in the group treated with subcutaneous Tocilizumab (47 patients) showed an even greater degree of therapeutic effectiveness. As high as $93.61 \%$ of patients achieved their therapeutic goal: remissions were reported in $25(53.19 \%)$ of patients and low disease activity in 19 (40.42\%). Three patients $(6.39 \%)$ had moderate disease activity and there were no cases with high RA activity (Graph 2A). Based on CDAI, one patient $(2.13 \%)$ had high disease activity and was the candidate for a change of therapy. Most of the patients (according to CDAI) had low disease activity (31-65.96\%), there were 10 $(21.27 \%)$ patients in remission, while $5(10.64 \%)$ patients had moderate disease activity. According to
CDAI, therapeutic goal was achieved in $87.23 \%$ of patients on subcutaneous Tocilizumab therapy (Graph 2B). The functional status measured using the HAQ index in patients on subcutaneous Tocilizumab therapy was 0.75 at the point of observation (indicating a low degree of functional damage).

After the switch from intravenous to subcutaneous Tocilizumab formulation, the number of patients with RA remission increased (from 7 to 12 at the observation point $-44.44 \%$ ), at the account of a reduced number of patients with low disease activity (from 15 to $10-37.04 \%$ ), while the number of those with moderate disease activity did not change - 5 patients $(18.52 \%)$ retained moderate RA activity (Graph 3). The analysis was done on 27 patients using the DAS 28 SE index.

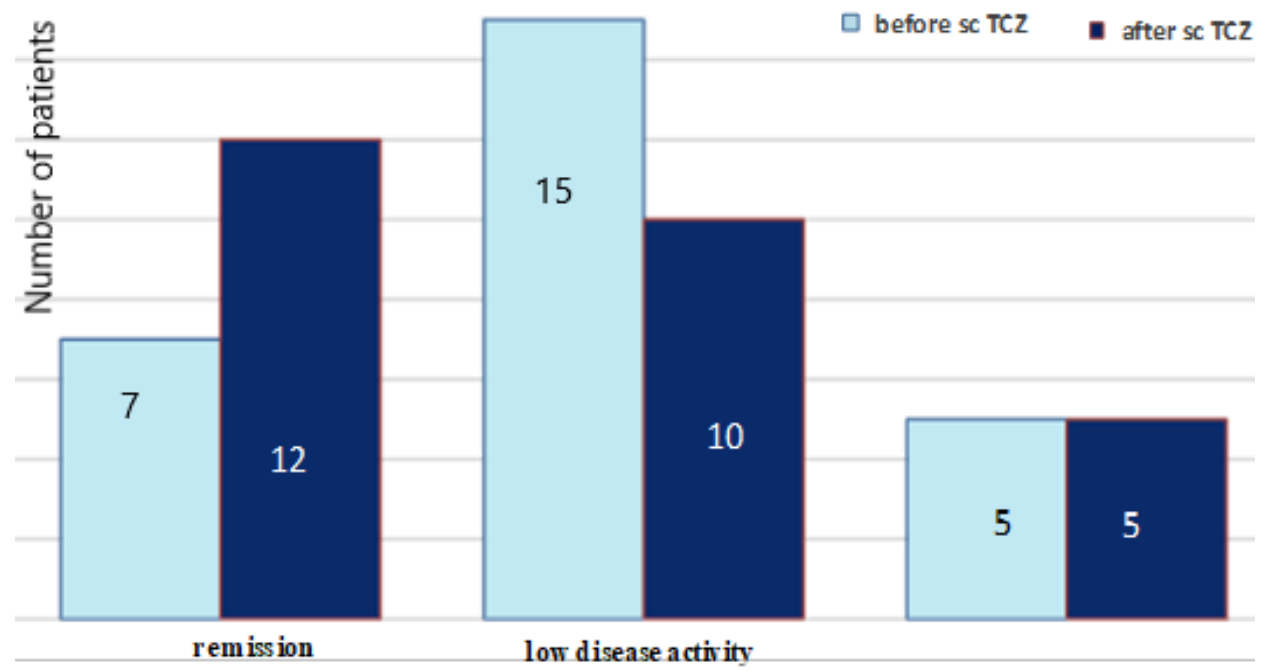

Graph 3. RA activity measured with DAS 28 SE after the TCZ switch (iv-sc)



Graph 4. Average values of $R A$ activity index in patients on iv-TCZ and after switching to sc-TCZ (DAS $28 S E-4 A ; C D A I-4 B$ ) 


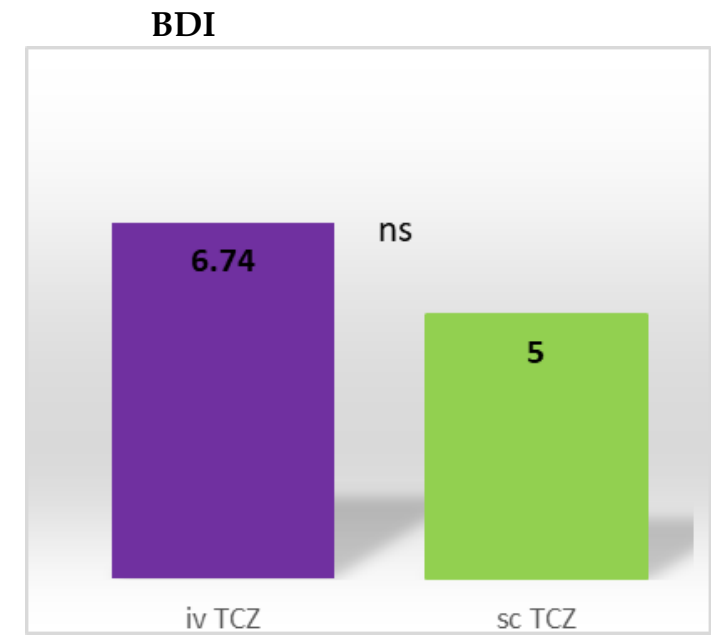

A
FACIT F

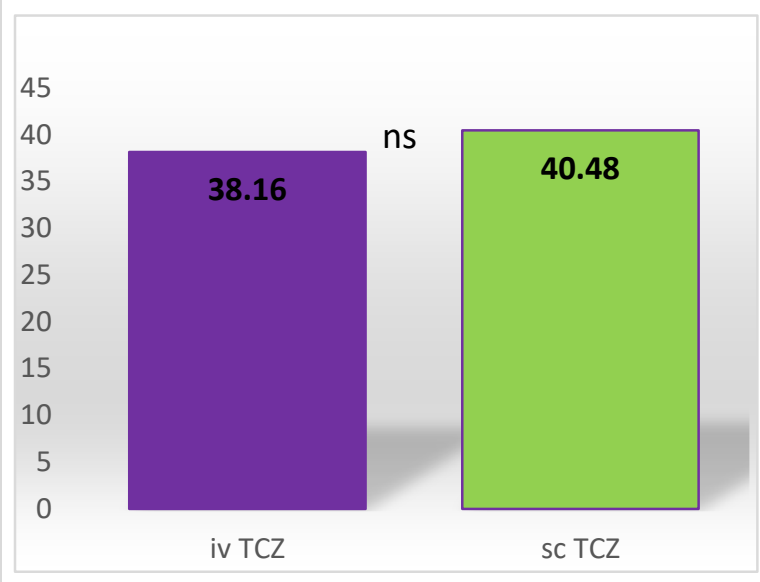

B

Graph 5. Beck Depression Inventory - BDI (5A) and FACIT F score (5B) after switching from iv-TCZ to sc-TCZ

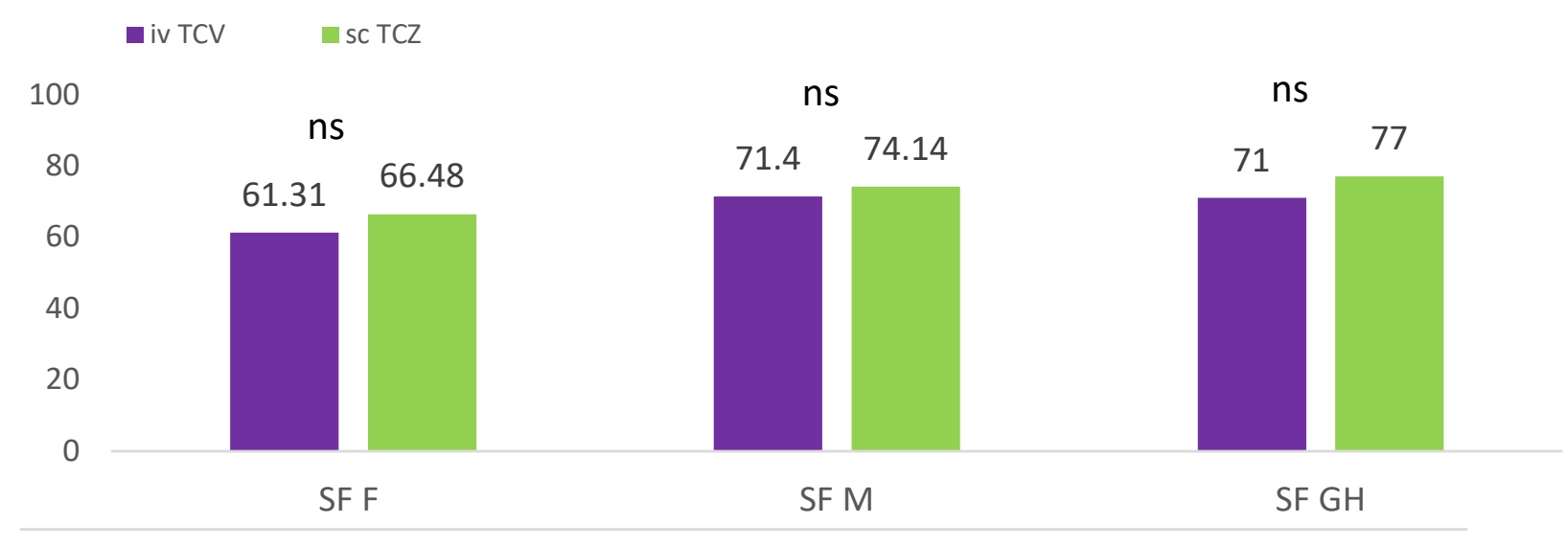

Graph 6. SF 36 questionnaire after the switch in TCZ administration SF F, functional domain; SF M, mental domain, SF GH global health assessment

Six months after the switch in TCZ administration (from iv to sc drug formulation), DAS 28 SE did not change considerably (the average index value before sc-TCZ was 2.44; six months after scTCZ introduction it was 2.46) (Graph 4A). Using the CDAI, we observed a significant decrease in the average values of this index (from 7.51 to 5.06) (Graph 4B).

The functional status, according to the HAQ questionnaire, did not differ significantly before and after 6 months of sc-TCZ therapy (0.83 vs 0.75 ).

Depression is a common comorbidity in RA. In our group, depression was found in $66.67 \%$ of patients, before and after the switch in drug adminis- tration. Beck Depression Inventory was used to compare the severity of depression symptoms among the groups (those treated with iv- or sc-TCZ). All the patients with depression had a low depression index $(<13)$ at the observation point, and the average value of Beck Depression index did not change markedly after the switch in drug administration (6.74 vs 5) (Graph 5A). Further, the switch in drug administration did not influence the degree of fatigue, according to FACIT F score (36.16 - iv-TCZ vs 40.48 - sc-TCZ) (Graph 5B).

SF 36 is the most commonly used questionnaire for the assessment of quality of life of patients with chronic arthritis. In this cross-sectional study, 
we compared the functional (SF F), mental component (SF M) of the questionnaire, as well as global patient-reported assessment of global health (SF GH) before and after 6 months of TCZ therapy. The indexes of functional, mental and global assessments of SF 36 were slightly higher after 6 months of scTCZ compared to iv-TCZ, but the difference was not statistically significant for all analyzed SF 36 components (Graph 6).

At the point of observation, all the patients who had switched from iv- to sc-TCZ were still on IL-6 blocker therapy (sc-TCZ). There were no adverse drug reactions which would cause TCZ withdrawal.

\section{DISCUSSION}

Tocilizumab is the first recombinant human monoclonal antibody against IL-6 receptor in RA therapy as an intravenous or subcutaneous formulation. The decision about the mode of administration lies with both the patients and their rheumatologists.

Our cross-sectional study is the first analysis in our country which compares the effectiveness of sc-TCZ after prior iv-TCZ therapy in everyday clinical rheumatology practice.

In our patient group, $88.68 \%$ agreed to switch from iv-TCZ to sc-TCZ therapy. Compared to the RoSwitch study (4), analyzing the sc-TCZ effectiveness 6 months after switching from iv-TCZ in RA patients in France, where $33.33 \%$ of the patients switched from one administration mode to another, a significantly larger number of patients here accepted the suggestion of their doctors to change their treatment administration. The difference might be explained by the new epidemiological situation (pandemia COVID 19) which influenced that a large number of our patients continue with sc-TCZ. In addition to a greater degree of comfort for the patients, this administration approach markedly reduced the number of visits to the centre, and reduced costs and pain resulting from venous access placement, which was the principal reason for their choice (together with reduced risks for infection). In the RoSwitch study, the patients who switched and continued with subcutaneous TCZ reported the following reasons for their choice: reduced number of visits to health care facilities $-71.4 \%$; greater patient autonomy $-40.5 \%$; economical reasons $-26.2 \%$; and pain with iv administration of the drug $-7.1 \%$. The patients who adhered to iv administration preferred that mode of administration because of the following: better patient monitoring during iv administration $-64.9 \%$; presence of doctors $-50.5 \%$; fear from allergic reactions $-31.2 \%$; frequency of subcutaneous injections $-30.9 \%$; opportunities for communication with other fellow patients $-23.6 \%$ (4). In our group, 6 patients continued with intravenous TCZ because they wanted to avoid more frequent subcutaneous injections and also stay in regular contact with their doctors.

Our analysis of the disease activity indexes for all patients who were on TCZ therapy (iv and sc) at the point of observation revealed high effectiveness of IL-6 blocker (both as monotherapy or combined with MTX). As high as $92.45 \%$ of patients achieved their therapeutic goal - low disease activity or remission (according to DAS 28 SE index). Such a result, confirming the high effectiveness of TCZ, agrees with the results of SUMMACTA study (3), which analyzed long-term effectiveness and safety of sc-TCZ compared to iv-TCZ and also reported high effectiveness of TCZ after 6 months of use $(37 \%$ of patients on iv-TCZ and the same percentage of patients on sc-TCZ achieved DAS 28 SE remission, while low disease activity was reported in $54.4 \%$ of patients on sc-TCZ and $49.7 \%$ of those on iv-TCZ). Six months after switching from iv-TCZ to sc-TCZ in our group, $44.44 \%$ of patients were in remission, a larger percentage than that in the SUMMACTA study (37\%), while the number of patients with low disease activity was lower in our group (37.04\%) compared to $56.8 \%$ in the SUMMACTA study. In both clinical studies, TCZ was highly effective, regardless of the drug formulation (iv or sc), and its therapeutic effectiveness was maintained as well after switching from iv-TCZ to sc-TCZ. We should also add that our results are the analysis of data from everyday clinical practice, while the SUMMACTA study was performed in controlled conditions. A group of French rheumatologists published the results of the RoSwitch study, a single-year observation study the primary goal of which was to establish the proportion of patients who were able to maintain low disease activity or remission six months after switching from iv-TCZ to sc-TCZ, and to compare the result with the number of patients who remained on iv-TCZ and had adequate control of RA (4). Six months after switching, more than $70 \%$ of patients in both groups achieved or maintained remission or low disease activity $(73.3 \%$ vs $70.3 \%)$, a proportion 
similar to our own results $(81.4 \%$ of patients in our study, after switching from iv-TCZ to sc-TCZ, achieved their therapeutic goal - low disease activity or remission). Functional ability of the patients (according to the HAQ score) did not differ as to the mode of drug application, which agreed with the results from clinical studies (3).

Depression is the most common comorbid condition in RA. The prevalence of depression according to the literature data ranges from $14 \%$ to $48 \%$, depending on the assessment and monitoring approaches (11). In our analysis, the symptoms of depression were present in a larger proportion of patients $(66.67 \%)$, which could perhaps be explained by longer average duration of RA (more than 6 years) and a longer interval till the introduction of biological drugs, TCZ included (more than 3 years). However, the Beck depressivity index was low in all of those who had depression symptoms and was not influenced by the mode of TCZ administration.

In earlier studies, a positive impact of TCZ on the degree of fatigue has been confirmed in RA patients (12). A significant reduction of fatigue severity was reported in the first weeks of TCZ administration. After the completion of FACIT F questionnaires (range $0-52$, with higher values indicating lower fatigue intensity) and comparison of average FACIT F scores in patients on iv-TCZ and sc-TCZ, we observed a low degree of fatigue, which did not change significantly after switching from iv-TCZ to sc-TCZ.

A group of Japanese authors have examined the impact of TCZ on quality of life during 24 weeks of treatment. A significantly better quality of life in all SF 36 domains was reported as early as in the fourth week of TCZ treatment (13). Our results also confirmed a positive impact of IL-6 blockers on the mental, physical and global components of SF 36 questionnaire and demonstrated that this effect was not dependent on the mode of TCZ administration.

\section{CONCLUSION}

During the six months of the therapy, Tocilizumab demonstrated a high degree of effectiveness regardless of the mode of administration (iv or sc), from both the point of view of doctors and point of view of RA patients. The change in the mode of administration (switching from iv-TCZ to sc-TCZ) did not have an impact on the already established good disease control and quality of life of patients with RA. 


\section{References}

1. Zlatković-Švenda MI, Stojanović RM, ŠipetićGrujičić SB. Guillemin F. Prevalence of rheumatoid arthritis in Serbia. Rheumatol Int 2014; 34: 649-58. https://doi.org/10.1007/s00296-013-2897-7

2. Smolen JS, Landewé RBM, Bijlsma JWJ, et al. EULAR recommendations for the management of rheumatoid arthritis with synthetic and biological disease-modifying antirheumatic drugs: 2019 update. Ann Rheum Dis 2020;79:685-99. http://dx.doi.org/10.1136/annrheumdis-2019-216655

3. Lauper $\mathrm{K}$, Mongin D, Iannone $\mathrm{F}$, et al. Comparative effectiveness of subcutaneous tocilizumab versus intravenous tocilizumab in a pan - European collaboration of registries. RMD Open 2018; 4: e000809.

https://doi.org/10.1136/rmdopen-2018-000809

4. Darloy J, Segaud N, Salmon HJ, et al. Tocilizumab Effectiveness After Switching from Intravenous to Subcutaneous Route in Patients with Rheumatoid Arthritis: The RoSwitch Study. Rheumatol Ther 2019; 6:61-75.

https://doi.org/10.1007/s40744-018-0138-y

5. Prevoo ML, van 't Hof MA, Kuper $\mathrm{HH}$, et al. Modified disease activity scores that include twenty-eight-joint counts. Development and validation in a prospective longitudinal study of patients with rheumatoid arthritis. Arthritis Rheumatol 1995; 38(1):44-8. PMID: 7818570 https://doi.org/10.1002/art.1780380107

6. Aletaha D, Smolen J. The Simplified Disease Activity Index (SDAI) and Clinical Disease Activity Index (CDAI) to monitor patients in standard clinical care, Best Pract Res Clin Rheumatol 2007; 21 (4): 663-75 https://doi.org/10.1016/j.berh.2007.02.004
7. Maska L, Anderson J, Michaud K. Measures of Functional Status and Quality of Life in Rheumatoid Arthritis. Arthritis Care Res 2011; 63 (S11): 4-13. https://doi.org/10.1002/acr.20620

8. Margaretten M, Julian L, Katz P, Yelin E. Depression in patients with rheumatoid arthritis: description, causes and mechanisms. Int J Clin Rheumtol 2011; 6: 617-23. https://doi.org/10.2217/I]R.11.6

9. Webster K, Cella D and Yost K. The Functional Assessment of Chronic Illness Therapy (FACIT) Measurement System: properties, applications, and interpretation; Health Qual Life Outcomes 2003, 1:79-85.

https:/doi.org/10.1186/1477-7525-1-79

10. Ware JE, Shelbourne CD. The MOS 36-item Short Form Health Survey (SF-36): conceptual framework and item selection. Med Care 1992; 30 (6):473-83.

http://www.jstor.org/stable/3765916

11. Matcham F, Rayner L, Steer S, Hotopf M. The prevalence of depression in rheumatoid arthritis: a systematic review and meta-analysis. Rheumatology 2013; 52:2136-48.

https://doi.org/10.1093/rheumatology/ket169

12. Geenen R, Dures E. A biopsychosocial network model of fatigue in rheumatoid arthritis: a systematic review, Rheumatology 2019; 58:v10-v21. https://doi.org/10.1093/rheumatology/kez403

13. Fusama M, Nakahara $H$, Hamano $Y$, et al. Improvement of health status evaluated by Arthritis Impact Measurement Scale 2 (AIMS-2) and Short Form-36 (SF-36) in patients with rheumatoid arthritis treated with tocilizumab. Mod Rheumatol 2013 23(2):276-83. https://doi.org/10.3109/s10165-012-0674-1 


\title{
Efektivnost tocilizumaba nakon prevođenja sa intravenske na subkutanu formulaciju kod bolesnika sa reumatoidnim artritisom - iskustvo jednog centra
}

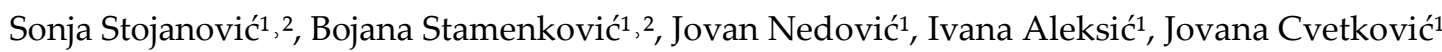 \\ ${ }^{1}$ Institut za lečenje i rehabilitaciju "Niska Banja", Niš, Srbija \\ ${ }^{2}$ Univerzitet u Nišu, Medicinski fakultet, Niš, Srbija
}

\section{SAŽETAK}

Dobra kontrola reumatoidnog artritisa danas podrazumeva odsustvo kliničke aktivnosti bolesti, usporavanje zglobne destrukcije i dobar kvalitet života obolelih. Uz danas dostupne terapijske modalitete, ovaj terapijski cilj dostižan je kod velikog broja bolesnika. U ovoj studiji preseka, ispitivali smo efektivnost IL-6 blokatora (tociluzimaba) kod bolesnika sa reumatoidnim artritisom (RA) u uslovima svakodnevne kliničke prakse. Takođe, analizirali smo i to da li promena načina administracije leka (prevođenje sa intravenskog na subkutanu formulaciju leka) utiče na efektivnost leka (korišćenjem DAS 28 SE i CDAI indeksa) i kvalitet života bolesnika sa reumatoidnim artritisom korišćenjem (HAQ, Beckov indeks deprsivnosti, FACIT F skor i SF 36 upitnik). Nakon 6 meseci praćenja i primene subkutanog tocilizumaba, zaključili smo da način administarcije leka ne utiče na efektivost i sve ispitivane parametre procene kvaliteta života.

Ključne reči: reumatoidni artritis, efektivnost, kvalitet života 